This article was downloaded by: [Sadirkhanov, Ruslan]

On: 11 December 2009

Access details: Access Details: [subscription number 917693044]

Publisher Routledge

Informa Ltd Registered in England and Wales Registered Number: 1072954 Registered office: Mortimer House, 3741 Mortimer Street, London W1T 3JH, UK

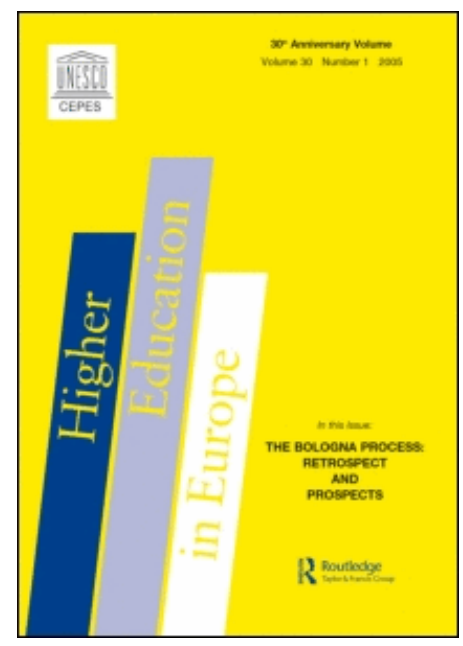

\title{
Higher Education in Europe
}

Publication details, including instructions for authors and subscription information: http://www.informaworld.com/smpp/title $\sim$ content=t713423578

\section{Employment Pattern Pressure for Pragmatic Change in Universities: Azerbaijan Case Study}

Ruslan Sadirkhanov

Online publication date: 11 December 2009

To cite this Article Sadirkhanov, Ruslan(2009) 'Employment Pattern Pressure for Pragmatic Change in Universities: Azerbaijan Case Study', Higher Education in Europe, 34: 3, 431 - 444

To link to this Article: DOI: $10.1080 / 03797720903356602$

URL: http://dx.doi.org/10.1080/03797720903356602

\section{PLEASE SCROLL DOWN FOR ARTICLE}

Full terms and conditions of use: http://www.informaworld.com/terms-and-conditions-of-access.pdf

This article may be used for research, teaching and private study purposes. Any substantial or systematic reproduction, re-distribution, re-selling, loan or sub-licensing, systematic supply or distribution in any form to anyone is expressly forbidden.

The publisher does not give any warranty express or implied or make any representation that the contents will be complete or accurate or up to date. The accuracy of any instructions, formulae and drug doses should be independently verified with primary sources. The publisher shall not be liable for any loss, actions, claims, proceedings, demand or costs or damages whatsoever or howsoever caused arising directly or indirectly in connection with or arising out of the use of this material. 


\title{
Employment Pattern Pressure for Pragmatic Change in Universities: Azerbaijan Case Study
}

\author{
RUSLAN SADIRKHANOV
}

This work reflects the results of a student survey and focus-group discussions and in-depth interviews with educators and policy practitioners to examine the connections between the higher education system and labour market demands in Azerbaijan. A notion of an Index of Students' Optimism regarding employment prospects has been introduced in this study. It is found that private university students are much more optimistic about employment opportunities as compared with their public university fellows. Available options are considered for the Azerbaijan state policy modernization in the higher education area that would promote students' capacity to cope with competitive challenges in the job market.

\section{Introduction ${ }^{1}$}

Any research on the effectiveness of higher education from the graduates' employment prospective and its relevance to the obtained tertiary-level qualification is of tremendous interest and represents a potential benefit. Nowadays, the process of expansion of the market influence on the trends of education is observed all over the world because of the new role of education as an essential tool for the achievement of a competitive economy.

One of the key issues is how to modernize the universities and the governmental policies in order to enhance students' capacity and provide them with the necessary skills to cope with the challenges of a competitive job market (Allen and van der Velden, 2001; Cardoso, 2004; Kellermann and Sagmeister, 2000; Mora et al., 2005; Paul et al., 2000; Teichler, 2005). This multi-faceted problem is of practical significance not only for the government and the universities, but also for the development of businesses in an expanding economy, as well as for the students and their parents.

The present study focuses on Azerbaijan, a country with the world-record growth of gross domestic product in past years. ${ }^{2}$ Here, a paradox has developed whereby the rate of unemployment among new graduates is growing on the background of an increasing need for qualified specialists. ${ }^{3}$

\footnotetext{
${ }^{1}$ This article is based on a research entitled "Employment of University Graduates and Pragmatic Transformation of Higher Education", which was funded by the Caucasus Research Resource Centers (CRRC) Azerbaijan - a programme of the Eurasia Partnership Foundation with funding from the Carnegie Corporation of New York. The statements and views expressed are solely the responsibility of the author. The author appreciates Anna Bushmann and Nana Papiashvili for their helpful suggestions and comments.

${ }^{2}$ See The State Committee of Statistics: http://www.azstat.org/macroeconomy/indexen.php or UNDP Azerbaijan Development Bulletin: http://www.un-az.org/undp/bulnews53/en3.php

${ }^{3}$ In Azerbaijan, among a few studies relevant to this subject, it is worth mentioning a work of F. Rzayev carried out by the grant of the Caucasus Research Resource Center; this study (in Azerbaijani) is characterized by saturated information material, including relevant statistics. At the same time, a few critical and analytical articles published in local newspapers reflect and analyze various problems that hinder the development of competitiveness in higher education in Azerbaijan. (see Information in Brief: http://www.crrc.az/index.php/lo/17/20)
} 


\section{Azerbaijan's Educational Environment: Situational Analysis in Brief}

As many other former Soviet republics, after the restoration of its independence in 1991, Azerbaijan has started to change its obsolete education system. Before 1991, all universities in Azerbaijan were established exclusively by the government; since 1991, new public and private universities began to appear in the country and among them only few of the private universities demonstrated competitiveness. Despite a number of statements and measures undertaken by the government on the transformation of the education system in accordance with the Bologna Process standards, with the purpose to be a part of the European educational environment, the low quality of higher education still remains. Azerbaijan is still a country with a transition economy, and this transition character is influencing its education system with the corresponding restrictions and barriers. The issue of the co-ordination of higher education with rapidly changing market demands becomes critical. The solution to this problem gets more urgent under the conditions of the commercialization of higher education on the one hand, and globalization and internationalization of the labour market on the other. In this situation, the percentage of employed graduates should be considered as one of the vital indicators of the profitability and efficiency of the university.

Of the employed population, 19.2 per cent are people with higher education degrees, and the overwhelming majority of them (about 72.4 per cent) are employed in the public sector. It is worth to note that 32.2 per cent of the unemployed individuals in Azerbaijan have higher education. Ultimately, every graduate is a product of the university, which consumes not only time but also a considerable amount of financial resources (regardless of whether it is state or privately financed). Ideally, this product should justify the total corresponding costs, not only to meet the demand for specialists on the market, but also to meet the expectation of those trained specialists. In any case, Azerbaijan universities should consider two questions in their development policy:

- What kind of specialists does the labour market need?

- What kind of syllabus and teachers are needed for the preparation of competitive specialists?

The Azerbaijan higher education system has the following structure: a basic twolevel professional training, which is carried out consistently as a four-year-long baccalaureate, completed with a bachelor degree and a two-year-long master's programme, completed with a master's degree, which can be followed by a three-year-long postgraduate education to carry out scientific research, leading to a doctoral degree. ${ }^{4}$ In 2004-2007, there were thirty-two public and fourteen private higher institutions in Azerbaijan that were located mostly in the capital city, Baku, with population about two million; the total number of students was 116,124, with 95,960 students enrolled in public universities and 20,164 in private universities. The total number of students (in private and public universities) enrolled in two-year-long master's programmes was 10,060. Approximately 82.6 per cent of all students were studying at public universities. In addition, there are several military profile higher education institutions, such as the High Military School of General Troops, Baku High Maritime School,

\footnotetext{
${ }^{4}$ See also, "Towards the European Higher Education Area. Bologna Process. Reports from New Members of the Bologna Process. Country”, http://www.bologna-bergen2005.no/EN/natio-nal_impl/New/041130_Azerbaijan.pdf; or Bologna Process and "Template For National Reports: 2005-2007: Republic of Azerbaijan", http:// www.ond.vlaanderen.be/hogeronderwijs/bologna/links/Nationalreports007/National_Report_Azerbaijan2007.pdf
} 
Azerbaijan High Aviation School, Baku High Polis Academy, or the Academy of National Security. In 2005-2006, there were 12,455 professors and teachers of higher education in the public sector; and 1987 in the private sector. ${ }^{5}$ Of these, 824 had a doctor of sciences degree and 5137 had a candidate of sciences degree (similar to $\mathrm{PhD}$ ). Due to the low pay in the education sector, the majority of the teachers had to work several jobs at various universities. Officially, the student:faculty ratio for daytime education was, on average, 9:1. As a whole, the official statistics does not reflect a number of important data concerning the needed resources and materials for higher education institutions. For example, there are no data on the average salary of the highest ranked teachers who have a doctoral or candidate of sciences degrees (it is known that the salary does not exceed US $\$ 200$ per month), no information about universities budget, space conditions, etc. It is also important to note that in a modern competitive global market, educational institutions cannot successfully develop, as long as its workforce - teachers are underpaid; and this crucial fact must be the primary challenge for the government.

There are still many questions concerning students' motivation, their personal mission, transition from school to university and from university to the market, specific features of the higher educated employment, job satisfaction of graduates, first-time job, etc.

The present work is aimed at both, the clarification of the problem of practical orientation of the higher education institutions in Azerbaijan, and the development of valid recommendations for the interested parties (universities, government, and business environment), with the purpose to achieve successful employment of graduates. ${ }^{6}$

\section{Employment and the Universities: Students' and Graduates' Opinions}

\section{Index of Students' Optimism Regarding Employment Prospects}

The following material was prepared on the basis of survey data from eight universities (public and private) located in Baku, collected in 2006 (see Note 6). This poll reflects the students' real expectations/concerns on their majors, as well as their assessment of the involvement of the university in students' employment upon graduation of the school. To preserve anonymity of results, in the following data the full names of the chosen universities are coded: public university BU (15,410 students) - 149 questioned

\footnotetext{
${ }^{5}$ The State Committee of Statistics: http://www.azstat.org/publications/azfigures/2007/en/007.shtml\#t7_7

${ }^{6}$ The following methodology was used by author to carry out this research:

- The quantitative analyses have been prepared on the basis of a survey applied at eight universities located in Baku (totalling 463 questionnaires at 4 state and 4 private universities) in order to obtain first-hand information about students' assumptions, needs and visions of their future employment. Being a part of the team consisting of members of the US-educated Azerbaijani Alumni Association that conducted the survey in 2006, the author had a leading role in the process of the questionnaire development and analysis of the obtained results.

- Two focus groups were formed by the author in Baku in order to identify and discuss issues impacting graduates of 2004-2006, and prioritize demands stated by the representatives of the Ministry of Labour and Social Protection of Population, the Ministry of Education, NGOs, employers and employment agencies.

- A round-table was held by the author with the participation of experts from universities, NGOs, and the World Bank-Azerbaijan, aimed at strengthening the practical component of the university education policy in condition when there is no real opportunity for value occupational training or internship for students.

- Six qualitative/individual interviews were conducted by the author with heads of three universities (two private and one state), chiefs of departments from the Ministry of Labour and Social Protection of Population, Ministry of Economic Development, and the Director of the Azerbaijan Bank Training Center to discuss current circumstances concerning the practical orientation of the higher education strategy in Azerbaijan and its adaptation to the requirements of the market economy.
} 
students; public university OA (6055 students) - 40 questioned; public university PAU (800 students) - 48 questioned; public university EU (14,920 students) - 40 questioned; private university WU (950 students) - 36 questioned; private university CU (1900 students ) - 40 questioned; private university KhU (850 students) - 40 questioned; and finally, private university OYU (2000 students) - 70 questioned; that makes up 463 questioned students, including 277 questioned students from public and 186 questioned students from private universities.

We analyzed the data received on three key questions (among another twenty-seven), which are correlated to an estimation of the utility of offered knowledge at university.

1. Will the knowledge you acquire at the university help you to find a job?

2. How good are your chances to find a job in your field of specialization?

3. Do you need an additional vocational training in order to find a job? ${ }^{7}$

Figures 1-3 distribute obtained answers to question 1 .

On average, more than half of the students positively evaluated the effectiveness of gained knowledge for subsequent employment. However, there was a huge difference in the estimations received from private and public universities. Figure 1 shows a striking contrast between public (first four on the left) and private (the next four towards right) university students' in Baku on whether they believed the knowledge they got at the university would help them to find a job. The distribution of the negative answers in regards to the effectiveness of the gained knowledge (Figure 2) shows a high level of pessimism among the students of the public universities. On average, this pessimism is estimated as 22.6 per cent; but in public universities, the pessimism is already measured at as much as 33.3 per cent, whereas in private universities it makes only 4.8 per cent.

Figure 1. Distribution OF THE "YeS" ANSWER TO THE QUESTION (1) IN THE SURVEY: "WILL THE KNOWLEDGE YOU ACQUIRE AT THE UNIVERSITY HELP YOU TO FIND A JOB?"

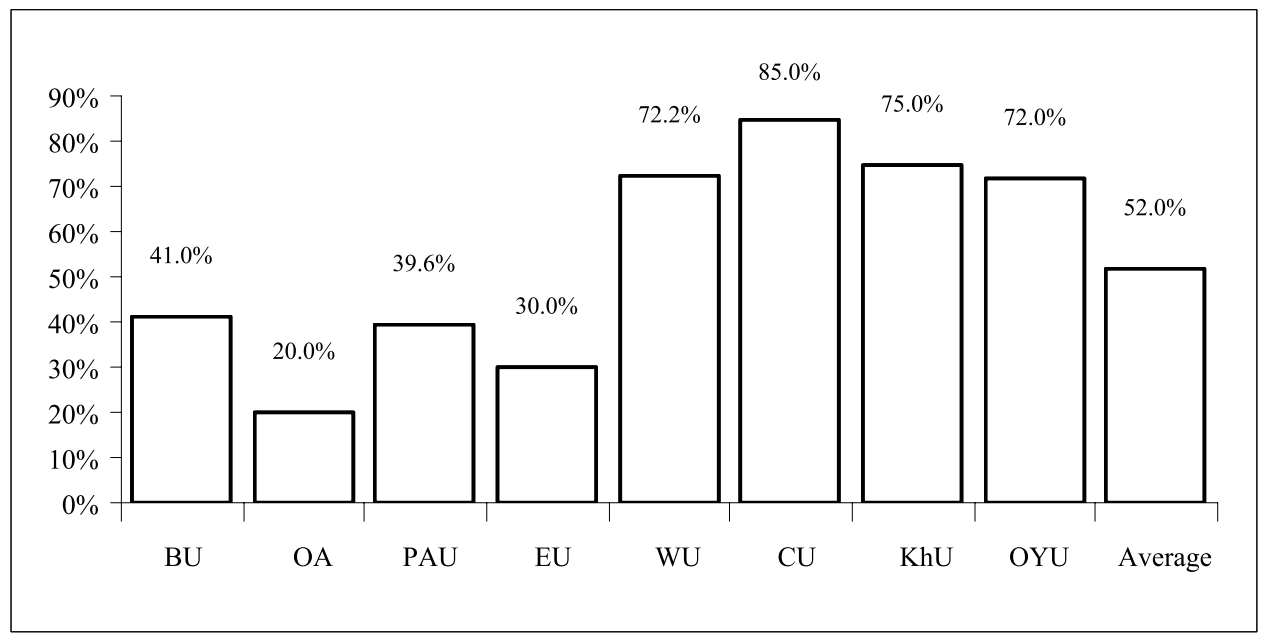

Source: The author.

\footnotetext{
${ }^{7}$ In framework of questions (1)-(3), average calculates as a weighted average, where weight is a number of questioned students from corresponding university.
} 
Figure 2. Distribution OF THE "No" ANSWER to THE QUESTION (1) IN THE SURVEY: "WiLL THE KNOWLEDGE YOU ACQUIRE AT THE UNIVERSITY HELP YOU TO FIND A JOB?"

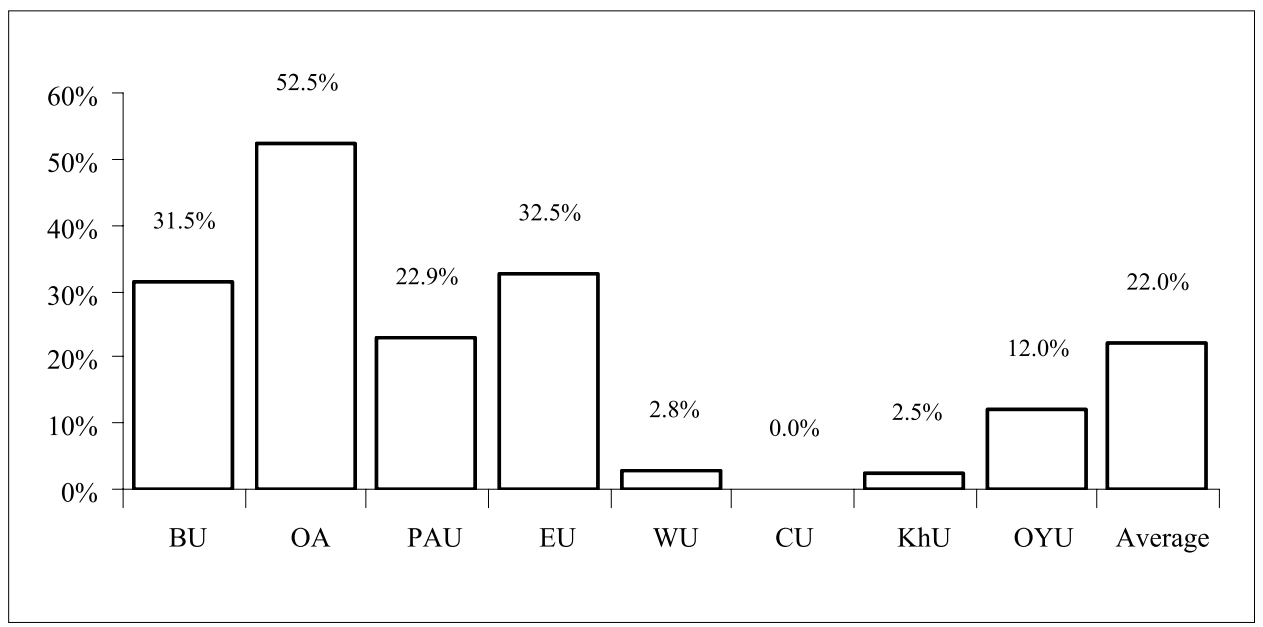

Source: The author.

FIgURE 3. DistribUtion OF THE "HARD TO ANSWER" ANSWER TO THE QUESTION (1) IN THE SURVEY: "WILL THE KNOWLEDGE YOU ACQUIRE AT THE UNIVERSITY HELP YOU TO FIND A JOB?"

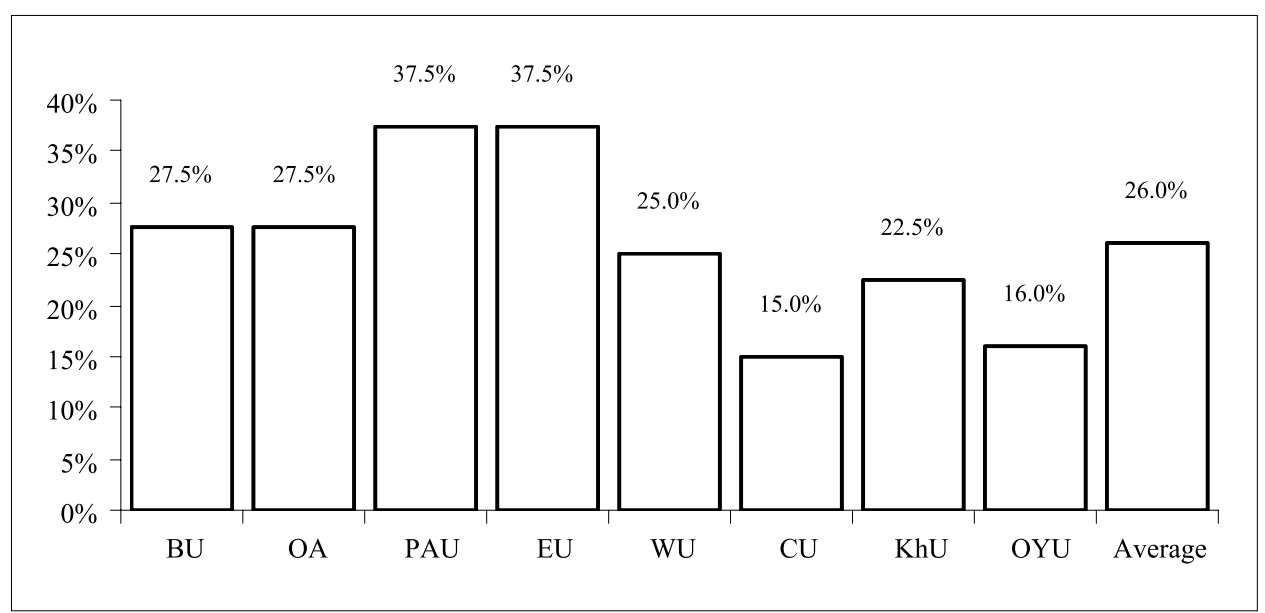

Source: The author.

Therefore, in the aggregate, students of private universities had essentially greater confidence in the effectiveness of gained knowledge, than their counterparts from the public schools.

The following information reflects answers obtained to question (2).

- High: 19.5 per cent for BU; 7.5 per cent for OA; 12.5 per cent for PAU; 32.5 per cent for EU; 27.8 per cent for WU; 47.5 per cent for $\mathrm{CU}$; 20 per cent for $\mathrm{KhU}$; 38 per cent for OYU. Average $=24.2$ per cent. 
- Middle: 55 per cent for BU; 22.5 per cent for OA; 70.8 per cent for PAU; 50 per cent for EU; 66.7 per cent for WU; 47.5 per cent for $\mathrm{CU} ; 70$ per cent for $\mathrm{KhU} ; 58$ per cent for OYU. Average $=55.3$ per cent .

- Low: 20 per cent for BU; 27.5 per cent for OA; 12.5 per cent for PAU; 10 per cent for EU; 5.6 per cent for WU; 2.5 per cent for $\mathrm{CU}$; 10 per cent for $\mathrm{KhU}$; 0 per cent for OYU. Average $=13.1$ per cent.

- $\quad$ Not at all: 5.4 per cent for BU; 42.5 per cent for OA; 4.2 per cent for PAU; 7.5 per cent for EU; 0 per cent for $\mathrm{WU} ; 2.5$ per cent for $\mathrm{CU}$; 0 per cent for $\mathrm{KhU}$; 4 per cent for OYU. Average $=7.5$ per cent.

The distribution of answers shows that, on average, 24.2 per cent of respondents had a high estimation of their chance to find a job in accordance with their university specialization. Nevertheless, the private universities showed considerably better statistics (33.7 per cent) than the public universities (18.4 per cent). The distribution of the answers stating middle expectations looks positive (on average, 55.3 per cent). Uniting the two types of answers concerning "high" and "middle" as positive, we received the following generalized Figure 4 of positive (high or middle) answers to the question (2).

The data in Figures 5-7 below were obtained according to the answers to question (3).

It is obvious from the presented distribution of answers (Figure 5) that the overwhelming majority of students highly valued the importance of the possibility to improve their practical skills in their specialty in order to get a subsequent employment.

It is quite reasonable to develop an index of student's optimism (i.s.o.) regarding employment prospects, which represents the arithmetic mean of "Yes" answers and is based on questions (1) "Will the knowledge you acquire at the university help you find a job?" and (2) "How good are your chances to find a job in your field of specialization?".

There is the following averaged characteristic of i.s.o. for the selected eight universities:

FIGURE 4. DistriBUtion OF THE POSITIVE ("HIGH" AND "MIDDLE") ANSWERS TO THE QUESTION (2) IN THE SURVEY: “HOW GOOD ARE YOUR CHANCES TO FIND A JOB IN YOUR FIELD OF SPECIALIZATION?"

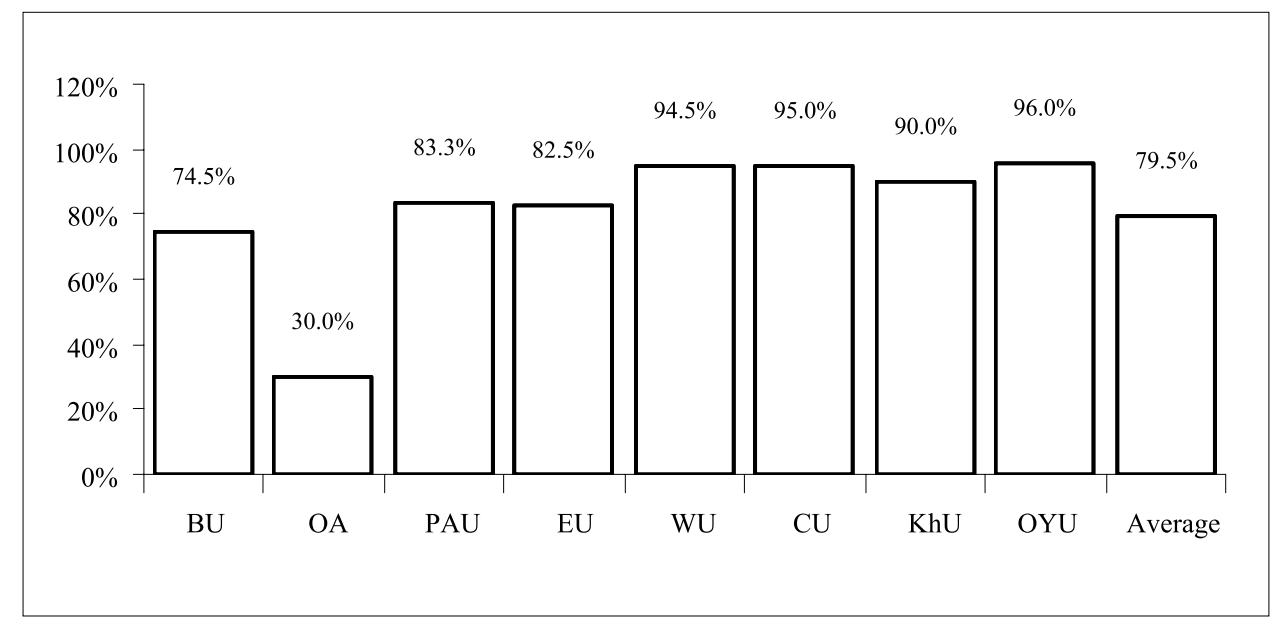

Source: The author. 
Figure 5. Distribution OF THE "YeS" ANSWER TO THE QUESTION (3) IN THE SURVEY: “DO YOU NEED AN ADDITIONAL VOCATIONAL TRAINING IN ORDER TO FIND A JOB?"

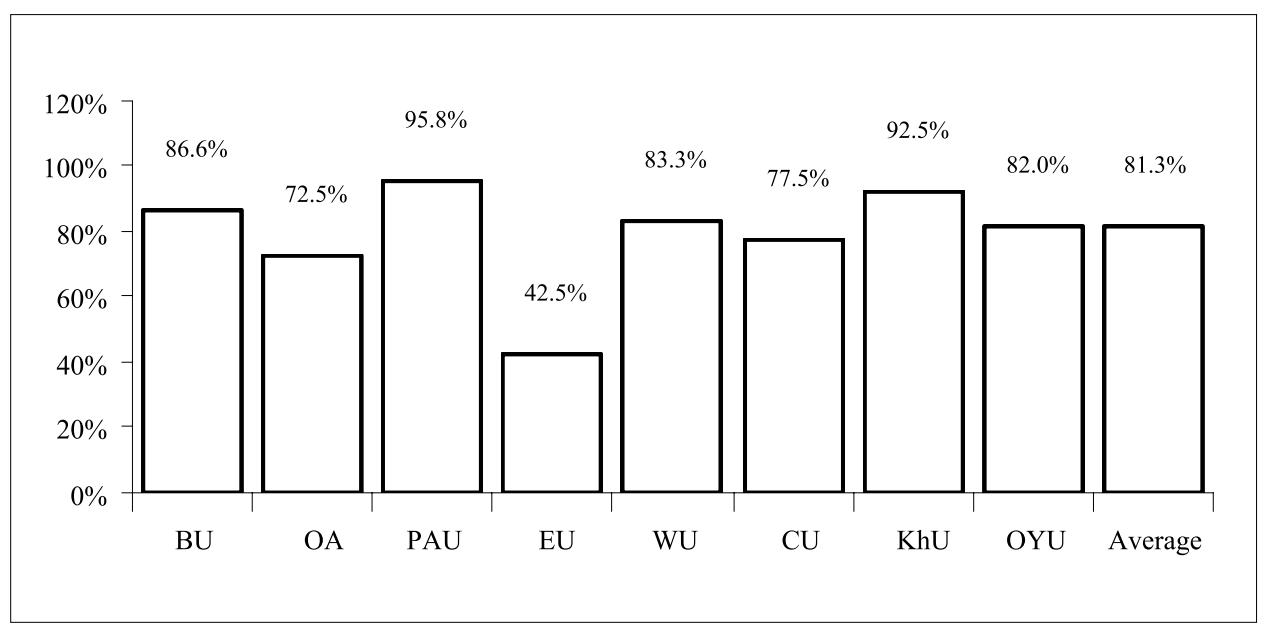

Source: The author.

Figure 6. DistribUtion OF THE "No" ANSWER TO THE QUESTION (3) IN THE SURVEY: "DO YOU NEED AN ADDITIONAL VOCATIONAL TRAINING IN ORDER TO FIND A JOB?"

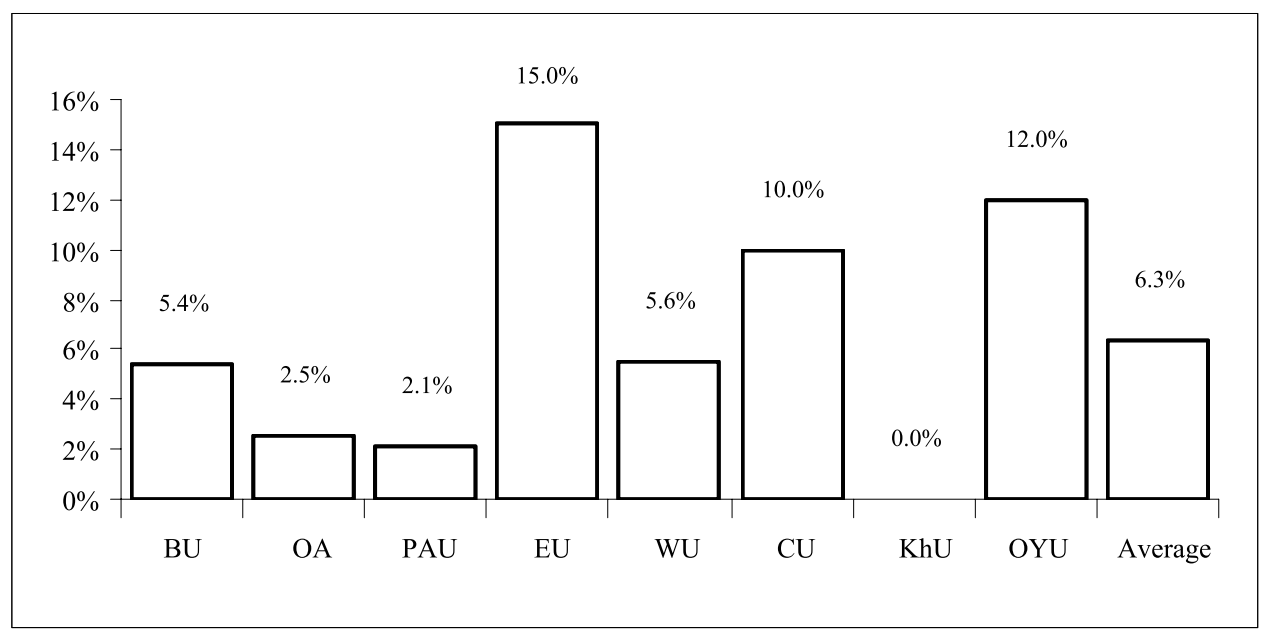

Source: The author.

$$
\text { i.s.o. }=\frac{79.5 \%+51.02 \%}{2} \approx 65.3 \% \text { or } 0.653 \text { as a numerical parameter. }
$$

The expression of the corresponding percentage of the i.s.o. regarding employment prospects for each university is described as follows.

In public universities i.s.o. is (approximately): 61.4 per cent or 0.614 for PAU; 57.7 per cent or 0.577 for $\mathrm{BU} ; 56.2$ per cent or 0.562 for $\mathrm{EU}$; and 25 per cent or 0.25 for OA. 
FIGURE 7. DistribUtion OF THE “HARD TO ANSWER” ANSWER TO THE QUESTION (3) IN THE SURVEY: "DO YOU NEED AN ADDITIONAL VOCATIONAL TRAINING IN ORDER TO FIND A JOB?"

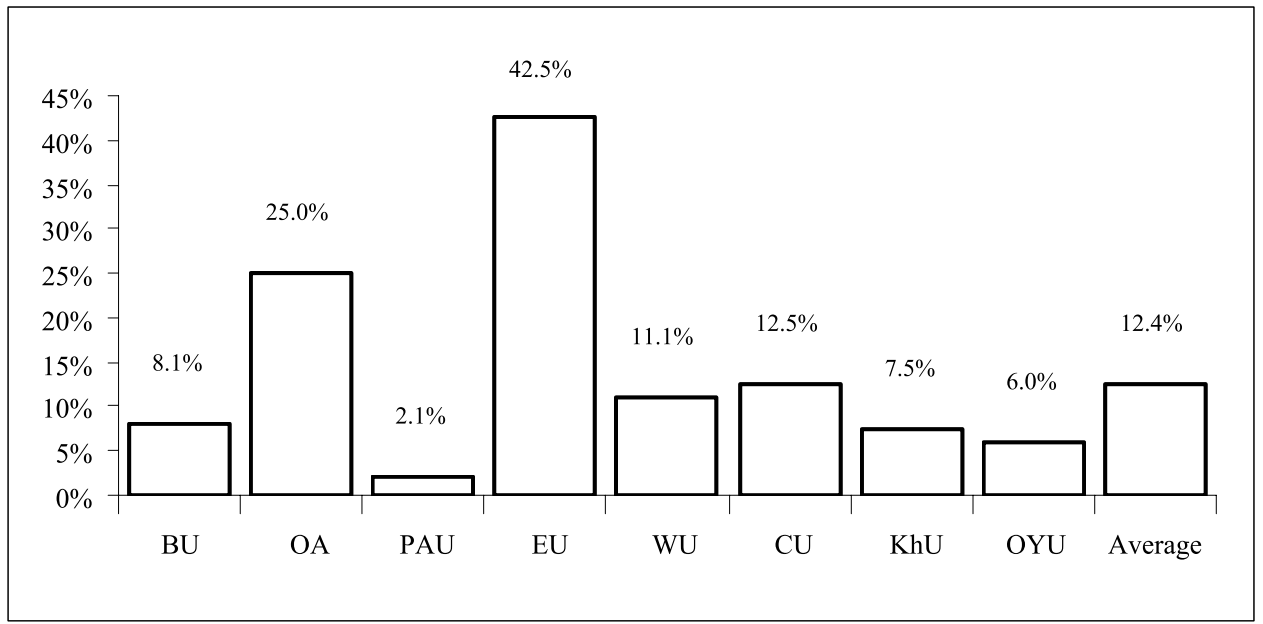

Source: The author.

In private universities i.s.o. is: 90 per cent or 0.9 for $\mathrm{CU}$; 84 per cent or 0.84 for OYU; 83.4 per cent or 0.834 for WU; and 82.5 per cent or 0.825 for KhU.

Apparently, from the received results in the presented particular case, i.s.o. is better at private universities. From this point of view, in the presented sample of eight universities, private universities, as a whole, have greater practical orientation. It should be noted that, unlike public universities of the country, private universities in Azerbaijan do not receive any financial support from the government. For their survival, private universities are compelled to show greater flexibility in adaptation of their education policy to labour market demands.

\section{Graduates' Viewpoint and their Concerns}

The following information reflects the results of focus group discussions held with participation of seven graduate respondents. They graduated from universities located in Baku, during 2004-2006. The primary goal of the focus group was to reveal and describe the basic obstacles impeding employment for graduates in the labour market in Baku during their transition from university to a labour market, as well as their expectations about appropriate changes in university education system. Debates were called to understand the typical problems that minimize the competitiveness of graduates. A point of issue is the variety of factors accompanying the basic chain: university - labour market - found workplace.

The majority of respondents (six out of seven) deemed that the university majors do not correspond to the current workforce demands; there is no opportunity to achieve a practical experience within the framework of the university education process which lowers the chance to find a job.

Nevertheless, all respondents believed that good university education, even if it does not correspond to the skills necessary for the currently taken position, is very important for effective adaptation to the requirements of the job; the better the education background is, the faster will be the adaptation process to new circumstances. 
The respondents reflected the following main factors in choosing the desired university: (1) a general representation about the future specialty; and/or (2) insufficient admission marks; and/or (3) absence of financial means to study at a better school.

The majority believed that teaching disciplines, which are not adequate to the chosen university specialty, should be reduced, whereas disciplines on a specialty should be intensified and modernized. The respondents deemed that special attention should be given to those university subjects that have a wide spectrum of application, even in the case of their independence from the specific specialty. They named subjects such as management, computer sciences, and foreign languages.

A particular opinion was stated for granting an opportunity of parallel studying of a supplementary subject/subjects; gained knowledge would sharply strengthen attraction of the major discipline. Some of them (five out of seven) believed that the presence of two or more professions would harshly strengthen their competitiveness. According to the respondents:

- obtained higher education does not take into account and does not correspond to the prospects of the developing national economy and business;

- $\quad$ in universities, teaching subjects are torn off reality and most of the used materials is outdated;

- teachers/professors practically do not use Information Technologies (IT) in the education process;

- universities have very limited contacts with rapidly developing oil sector and business.

The respondents think that in Baku, the organizations conducting general and vocational training, are either very expensive (like The British Council), or not available to the majority (such as the training programmes and seminars of British Petroleum Azerbaijan).

The Respondents also believed that the government should help them by means of allowances in the first months after graduation. This opportunity will help them to choose a more suitable job.

Many (four out of seven) noted that professional development demands efforts for self-education, such as visiting seminars, performance of more complex work, etc. For this reason, some graduates (three out of seven) were reluctant to invest in their career paths providing that their current salary afforded them a relatively good lifestyle.

Finally, the respondents marked that general skills/competences (like knowledge of foreign languages, computer skills, certain types of training, etc) often play a more significant role in the employment process than the existence of a university diploma.

Conclusions:

- As a whole, all respondents had employment problems.

- The government and the universities do not play any significant role in the respondents' transition from university to employment.

- All respondents strongly criticize university education for being very formal and torn off from practice.

- The respondents need professional and practical knowledge and skills that have not been received at the university.

- The Government, with the assistance of the universities and business environment, should organize a system of widely accessible practical training for graduates, on a regular basis. 


\section{Pragmatic Higher Education and Employer Requirements}

The following information reflects discussions of the focus group whose seven respondents represented the following companies and organizations: BP-Azerbaijan; ATTAS PR/Anglo American Alliance; the National Academy of Sciences; the Ministry of Labour and Social Protection of Population; the Ministry of Education; the Engineering Company "Maxiwell" and Azerbaijan Banks Association.

The discussions were focused on the issue of pragmatic higher education and employers' requirements to graduates.

The majority of respondents preferred modern private universities Khazar and Qafqaz to the public universities. In their opinion, these universities are distinguished from the others owing to:

- contemporary/updated curriculum and training programmes;

- greater opportunities for continuing education (including education abroad);

- practical and effective partnership with employers;

- involvement in their students' post-graduation employment.

As a whole, the respondents placed the basic emphasis on the individual quality of graduates' knowledge as well as their competency range, which are important for professional development.

The majority of the organizations (two state and three business) represented by respondents has occasional contacts with universities. There is no long-term strategic planning. Regarding the influence of the vocational training quality on the process of graduates' employment, their wages and prospect of career growth, the respondents representing the private sector evaded from commenting, motivating/handling it as a commercial secret. The respondents representing the public sector noted that the typical scale of salaries per month is minimum US\$100 (the National Academy of Sciences) and maximum US\$460 (Ministry of Labour and Social Protection of Population).

The majority of respondents (five out of seven) noted that graduates are compelled to work in areas beyond their university degree; there are various reasons for this situation: limited job positions require university education; the low salaries paid for manufacture, schools and hospitals jobs; etc. Many graduates who have university diplomas and even scientific degrees work in firms, shops, hotels where their university knowledge is not demanded; as a result, they are losing their professional qualification. All respondents from the business sector noted the existence of a contradictory situation, when alongside with an acute necessity for graduate experts, it is very difficult to pick up a candidate with the required level of professionalism from among hundreds of jobseekers holding formal diplomas in the corresponding specialty.

A foreign language (especially English) is a tool for international communication. There is a dilemma regarding the choice of the language (national language - foreign language) of education system i.e. what should be the language/languages of education? On the one hand, the knowledge of foreign languages is an important advantage for the continuation of education in the future; on the other hand, remembering the rude domination of the Russian language in the near Soviet past, giving priority to any foreign language (in work or education) is an additional risk factor for the development of the national language, Azerbaijani.

According to the opinion of the respondent-representatives of the private sector, it is necessary to develop the state policy, precisely considering material incentives for 
teachers as a key point in the process of developing quality education, as well as the status of civil servant for them. Alongside benefits, the rapidly growing budget of Azerbaijan economy generates certain problems; for example, the one-sided development, mostly focusing on oil benefits. Therefore, the need for specialists in various fields will depend on the economic policy of the state. Azerbaijan should not lose its scientific, technical and pedagogical potential that it still has. For this purpose, it is necessary to stimulate the development of new industries on the basis of applied researches in universities.

\section{Strengthening the Practical Constituent of a University Education Policy Package}

The following three questions were introduced during the round-table activity with leading experts from universities, local and international nongovernmental organizations in the field of education and the World Bank in Azerbaijan. ${ }^{8}$

a. How can the practical orientation of the existing university education be estimated in Azerbaijan?

b. How acceptable is the idea of creating in Baku an inter-university "Vocational Development Center"? (This idea was presented and justified in Sadirkhanov and Kengerlinskiy [2005])

c. How could the national business sector be involved in the process of vocational training for senior students as well as for graduates?

On the whole, the discussions were aimed at strengthening the practical component of the university education policy, given the fact that there is no real opportunity for occupational training or internship for students. The existing problems, which are impeding the development of professional higher education, have been recognized by respondents as serious challenges which are lowering the competitiveness of the educational environment of Azerbaijan.

Possible assistance in updating the Azerbaijan professional higher education system was discussed, especially in promoting the maximum capitalization of the human and social potential of the country. A point of issue, in this respect, is the choice and substantiation of a suitable form of interaction between universities that should be suppliers of the graduates demanded by the labour market, on the one hand, and employers from various sectors of the national economy, on the other. In this connection, the round-table participants supported the model of the mentioned Vocational Development Centre for senior students and graduates as an achievable format for universities. According to the round table discussions, some opportunities and tasks concerning the Centre's key activities could be:

- organizational field of interaction between universities and employers;

- studying demands of employers;

\footnotetext{
${ }^{8}$ Round-table participants: Murad Bagirzade (Professor, PhD, Head of Chair "Public Administration and Management", State Public Administration University), Tair Faradov (PhD, Senior Research Fellow, International Center for Social Research), Magomed Nuriyev (Professor, Doctor of Sciences, Vice-rector and Dean of Business School, Khazar University), Ibrahim Ismayilov (Expert on education programmes, Odlar Yurdu University), Saida Bagirly (Operation Officer/External Affairs, the World Bank), Elvira Anadolu (Expert, Human Development Unit, the World Bank Group), Bahar Haji-zadeh (Director, Baku Education Information Center), Ismail Ismailov (PhD, Assistant Professor, University Azerbaijan).
} 
- elaboration or specification of the character of the professions' standards;

- elaboration of programmes for training;

- elaboration of educational process models for the Centre;

- elaboration of an evaluation system for the main activities of the Centre;

- licensing and certification of professions received at the Centre;

- mentorship at the Centre;

- internship at the Centre;

- assistance in employment;

- studying foreign experience and its adaptation.

The Centre could be presented as the pilot model for additional higher vocational training in Azerbaijan.

A plan of further actions where education should play a more active role in national competitiveness was also outlined:

- Research and practical adaptation of the experience of the existing various models of interaction between universities and employers.

- Regular analyses of the following triad: education-science-manufacturing.

According to the participants' opinion, any attempts to modernize higher education in Azerbaijan will collide with the necessity of a deeper study of the fundamental issues, such as the teacher's problems (including worthy financing and teaching quality), the need of flexibility with regard to the supply and demand for specialties, etc. The responsibility of the university for each graduate should be considered more seriously. In the specific case of Azerbaijan, it is necessary to stimulate (possibly by relevant tax regulations) those universities whose graduates (for example, not below 50 per cent of them) find a job in accordance with the received university qualification within the first year after graduation. Such requirements to universities will stimulate a greater attention to the practical orientation of the existing higher education system. In the beginning, the inter-university Vocational Development Centre could be established as a shareholders' (mainly, universities, the state structures and the business sector) project, and further it may gradually become fully self-providing. All other functions and duties of the Centre, in addition to those mentioned previously can be entered progressively in accordance with the arising demands.

\section{Real Circumstances Concerning the Practical Orientation of Higher Education in Azerbaijan after the Soviet Past}

In the framework of the questions (a)-(c), the concept of the Vocational Development Centre for students and graduates was put forward, as a possible synergy project of the public universities and the business sector through six qualitative/individual interviews that were conducted with the heads of three universities (two public: Odlar Yurdu University, Khazar University, and one public: the State Tourism University), chiefs of the departments from the Ministry of Labour and Social Protection of Population, the Ministry of Economic Development, and the Director of Azerbaijan Bank Training Center. The information below represents a brief summary of these interviews.

During the period of the Soviet planned system, the practical component of higher education was implemented by means of obligatory professional practice periods in accordance with the university qualification; moreover, education was free-of-charge 
and universities did not bear any financial responsibilities for the accomplishment of the finishing stage of education in university, consisting of a seven- to ten-month period of practical training for students. But, despite the formal advantage of the Soviet higher education, which guaranteed workplaces for graduates, there was no significant difference in terms of high occupational preparedness and salary worthiness. The average salary for graduates was less than the equivalent of US\$300 per month.

The situation was sharply complicated after Azerbaijan gained its independence, as a result of the collapse of the USSR. Today, formally, all students should pass practice; but there are few organizations and companies where it is possible to send students for an internship. Leading private universities are compelled to create specialized commercial structures (for example, legal or medical clinics, etc. which is very expensive for the university) where students have limited opportunity to get practical skills. In rare cases, some universities have agreements with private companies, banks, and other organizations to carry out some practice for students.

The arisen dilemma regarding the needs for professionals and graduates' unemployment is partly the result of the policy of isolation from the market realities, which is typical for most of the universities. On the one hand, there are some out-of-date subjects that are being taught in graduate schools; on the other hand, not enough attention is given to specialization. In order to overcome the aforementioned problems, universities must update their curriculum and strongly adhere to a more narrowed specialization. It is necessary to pass from the still-in-force old Soviet principle of knowing widely in many areas to the principle of obtaining a narrower specialization, thoroughly and precisely. The achievement of a reasonable combination of theoretical and practical preparedness of the university students in accordance with the market demands is a primary problem of the Azerbaijan higher education system.

In general, there are similar disadvantages. Firstly, most of the students do not have a clear motivation for studying at the university, and especially for a chosen major. Secondly, they don't have any clear information about their future work requirements.

The idea of implementing a Vocational Development Centre on a cooperative/share basis by some of the universities will allow saving a significant part of the financial assets and human resources. State's involvement on behalf of the interested ministries will sharply lift up both the prestige and the quality of the Centre. It is important to avoid any monopoly in this area.

Despite the fact that about 90 per cent of the Azerbaijan gross domestic product has been represented by the private sector, the overwhelming majority of Azerbaijan business, with few exceptions, does not represent a large-scale enterprise where the presence of hundreds of highly qualified graduates is vital. On the other hand, in many cases the private sector's policy is to avoid any spending on students' education or training. Leaning on the experience of the Azerbaijan Bank Training Centre or Khazar University, it is possible to state that success consists in flexibility and widely reflecting the practice needs in the university policy.

\section{Key Conclusions and Recommendations}

Being an influential area, the labour market of graduates in Baku is not scientifically enough researched. Especially, such questions as effective long-time employment policy for graduates and fundamental university transformation in accordance with 
market requirements have to be in the focus of further research. Indicators like the i.s.o. regarding employment prospects should be widely developed and analyzed in order to assist the effective and practical orientation of university. In this regard appropriate financial support, as well as the government's active participation, are required. The existing rare attempts to describe the unemployment problems do not reveal the crucial obstacle of the majority of graduates who are considered to be 'specialists' on a paper only.

The problems related to the deterioration of the university environment in Azerbaijan have two basic causes: one is the inflexible curriculum and obsolete teaching technology, as well as the cheap wages of teachers; and another one is the defective internship system. Moreover, the tendency to prefer graduates with general competences, without crediting their professional skills, decreases the importance of university as the main source for receiving professional education.

In circumstances when, on the one hand, there is no real opportunity of full occupational training or internships for students and, on the other hand, the national business sector does not play the role of an active customer interested in university experts, one possible approach to the achievement of the practical orientation of universities and their adaptation to the market economy's requirements is the creation of specialized interuniversity occupational training structures.

Until now, the national private sector has not opted to participate in the development process of university education. This erroneous policy is leading to weakening of competitiveness of national business and to braking university modernization. There is an urgent need to develop the state stimulating policy for Azerbaijan business to be a prime customer of the university environment.

\section{References}

Allen, J. and VAN DeR Velden, R. "Transition from Higher Education to Work". Paper presented to the International Seminar "Educacion Superior y Empleo: La Situación de los Jóvenes Titulados in Europa", Universidad de Granada, Spain, 8-9 November, 2001.

CARDoso, A. "Jobs for Young University Graduates: Is It Worth Having A Degree?", in The EALE/SOLE World Conference 2005. Theme 6: Labour Demand and Employment. Bonn, Germany: IZA Bonn, University of Minho and CEPR, 2004, pp.1-14.

KellermanN, P. and SAgmeister, G. "Higher Education and Graduate Employment in Austria", European Journal of Education 352 (2000): 157-164.

Mora, J.-G., Garcia-Montalvo, J. and Garcia-Aracil, A. "European Higher Education Graduates and Job Satisfaction", European Journal of Education 401 (2005): 35-44.

PAUl, J., TEICHLER, U. and VAN DER VELDEN, R. "Higher Education and Graduate Employment", European Journal of Education 352 (2000): 141-156.

SADIRKHANOV, R. and KENGERLINSKIY, L. "Стратегия практической направленности высшегс бразования в Азербайджане" [A Strategy for Practical Orientation of Azerbaijan Higher Education], in A. Valiyev, ed. The Scientific and Pedagogical News of Odlar Yurdu University, Series of Legal, Social, Public, Economical, Philological and Pedagogical Sciences Volume 16. Baku: Odlar Yurdu University, 2005, pp. 96-100.

TEICHLER, U. New Perspectives for Learning - Briefing Paper 10. Higher Education and Graduate Employment in Europe. New Perspectives for Learning. Ely, UK: PJB Associates, 2005. 